\title{
Racial equality in France and the United States: media coverage of professional tennis players
}

\section{Rahsaan Maxwell}

To cite this article: Rahsaan Maxwell (2017) Racial equality in France and the United States: media coverage of professional tennis players, Ethnic and Racial Studies, 40:4, 656-674, DOI: 10.1080/01419870.2016.1181271

To link to this article: http://dx.doi.org/10.1080/01419870.2016.1181271

View supplementary material ¿

曲 Published online: 02 Jun 2016.

Submit your article to this journal $\widetilde{ }$

щ Article views: 61

Q View related articles ¿

View Crossmark data $\asymp$ 


\title{
Racial equality in France and the United States: media coverage of professional tennis players
}

\author{
Rahsaan Maxwell \\ Department of Political Science, University of North Carolina at Chapel Hill, Chapel Hill, NC, \\ USA
}

\begin{abstract}
I engage debates about racial media bias by analysing newspaper coverage of professional tennis players in France and the United States. Tennis is an elite sport that typically does not have many non-white players and may be especially sensitive to racial boundaries. Tennis also offers a new solution to the methodological challenge of establishing that any difference in newspaper coverage across racial groups is due to bias and not actual differences across the groups. I use the professional tennis ranking system, which assigns an objective marker of how good a player is (and therefore the media coverage that $s /$ he should receive) at any point in time. I explore two types of bias (the amount and tone of media coverage) and uncover no systematic racial differences in the relationship between ranking and media coverage. My findings have several implications for our understanding of racial boundaries and the media.
\end{abstract}

ARTICLE HISTORY Received 24 September 2015; Accepted 14 April 2016

KEYWORDS Race; media bias; sports; tennis; France; United States

\section{Introduction}

For most of the twentieth century, North American and West European mass media exhibited clear bias against racial minorities. Mainstream media tended to rely on negative stereotypes and depicted racial minorities as inferior to the majority population (Entman and Rojecki 2001). These biases were significant because media reflect existing societal norms, shape public opinion and contribute to the framing of policy agendas (Baumgartner and Jones 2009).

Recent evidence suggests that the media may be evolving towards less overt racial bias. Demographic trends in America and Europe have led to increasingly prominent non-white elites who contradict the assumption that racial minorities are fit only for the lower rungs of society (Alba and Foner 2015). Activists have also successfully mobilized for more respect for

CONTACT Rahsaan Maxwell rahsaan@email.unc.edu

(4) Supplemental data for this article can be accessed at 10.1080/01419870.2016.1181271.

(c) 2016 Informa UK Limited, trading as Taylor \& Francis Group 
minorities and more protection against discrimination (Lee 2002; Wihtol de Wenden and Leveau 2001). As a result, contemporary mainstream media and public discourse are less likely to exhibit overt expressions of anti-minority racial bias (Wilson, Gutiérrez and Chao 2012).

However, the diminution of overt bias does not mean that media are now free of racism. Race is a construct embedded in society, so as society changes we should expect racial boundaries and racist expressions to also evolve over time. One contemporary form of racism is in the proliferation of specialized online media. In particular, the comments and discussion sections of websites allow people to anonymously vent racist discourse that they would likely not utter in public (Love and Hughey 2015). Racism also continues to exist in language and actions that appear to be race-neutral but in reality are biased against minorities (Bonilla-Silva 2003). For example, mainstream media may not explicitly mention the race of their subjects but may use different adjectives to describe people of different races, or they may devote more (or less) attention to stories that are (not) consistent with existing racial stereotypes. Therefore, the simultaneous trends of decreasing overt bias and persistent covert bias raise questions about the extent to which American and European media (as well as the broader societies) are racially egalitarian.

\section{Media coverage of professional tennis players}

I engage debates about media bias by analysing newspaper coverage of professional tennis players in France and the United States (US). Sport is a domain in which stereotypes about intellectual and physical differences across races are especially vivid (Hughey and Goss 2015). Sport is also a central aspect of popular culture with broad economic, political and emotional resonance.

Professional tennis provides unique insight into racial egalitarianism because it is an elite sport in France and the US, and typically does not have many non-white players (Gillmeister 1998). Successful non-whites in elite white sports contradict stereotypes about what is expected of nonwhites and may provoke a backlash from whites invested in policing racial boundaries. By analysing the media coverage of professional tennis players I focus on a sport where racial boundaries may be especially sensitive.

\section{Professional tennis and racial minorities in France and the US}

France and the US are useful cases for analysing media coverage of professional tennis players because both are major tennis nations that consistently have top ranked male and female players. Both countries have been important in the historical development of tennis and of the four major tennis tournaments, one is in France (the French Open) and one is in the US (the US Open). 
France and the US also have long and complicated histories with non-white tennis players. Both countries had prominent non-white tennis champions during the mid to late twentieth century: Yannick Noah in France and Althea Gibson and Arthur Ashe in the US. During their careers, Noah, Gibson and Ashe faced explicitly racist treatment from the media, fans and other tennis players (Djata 2008). Overt racial bias is no longer socially acceptable and Noah, Gibson and Ashe are now revered as great champions in their respective countries (Harris and Kyle-DeBose 2007). Nonetheless, France and the US have had several controversies in recent years in which non-white tennis players were subject to racially charged comments by fans and journalists (Clarey 2015; Jules 2009). ${ }^{1}$ Therefore, the extent to which racial bias exists in French and American tennis coverage is an ongoing question.

Analysing media bias in France and the US also provides a contrast between two countries with different norms for dealing with racial diversity. ${ }^{2}$ In the US, race is one of the most significant social categories (Emirbayer and Desmond 2015). The white/non-white racial distinction began with state-sanctioned slavery, continued through the Jim Crow era, and remains relevant in contemporary society where many non-whites experience de facto segregation (Omi and Winant 2015). Successive waves of immigrants from around the world have also been racialized into the white/non-white spectrum as part of their integration into American society. The primacy of the racial divide in the US also means that political campaigns and public policy are often explicitly organized around ethnic and racial interest groups (Leighley 2001), and cultural practices with specific ethnic and racial origins are generally considered legitimate contributions to the national community (Alba and Foner 2015).

In France, race is a marginalized social category. The French Revolution privileged unity and equality among citizens by fighting against the most salient cleavages of the time: religion, social class and sub-national region (Weil 2002). In addition, prior to the 1950s, racial diversity was largely confined to France's overseas territories and colonies, which reinforced its marginality as a category. Things changed in the decades following WWII, when an influx of migrants from Africa, Asia and the Caribbean settled in metropolitan France (Ndiaye 2008). However, the dominant French republican identity continued to emphasize citizenship as the most important category for the national community. Race and ethnicity are now considered dangerous categories in France because using them for policy and public discourse would divide the population and limit the possibilities for social cohesion (Weil 2011). This means there are strict legal limits on the collection of data using ethnic or racial categories in France (Simon 2008). It is considered taboo to mobilize politically around minority identities in France and displays of minority cultural identity are highly stigmatized in the public sphere (Maxwell 2012). In the next section I explore how different norms for using racial categories generate different predictions for media bias in the two countries. ${ }^{3}$ 


\section{Generating hypotheses}

Existing literature generates four hypotheses about media bias in France and the US. One hypothesis is that there will be no mainstream media racial bias in either country. Both countries have had successful social movements in recent decades that pushed for better treatment of racial minorities (Lee 2002; Wihtol de Wenden and Leveau 2001). As a result, both countries have developed anti-discrimination norms that promote racial equality as the desired and legitimate goal for public life, and which should be especially salient in the highly visible domain of mainstream media (Givens and Case 2014; Sabbagh 2011). To be clear, this hypothesis does not rest on the assumption that France and the US are free of racial prejudice. Instead, the logic is that while people may have latent prejudices about racial minorities, both countries have strong norms of equal treatment and egalitarian public spheres (Sniderman and Carmines 1997; Weil 2011).

H1: Mainstream media in France and the US do not exhibit racial bias.

A second hypothesis is less sanguine about the progress of racial equality. This argument highlights the fact that both countries are fundamentally organized around a hierarchy with whites at the top and non-whites at the bottom (Lamont 2000). Therefore, even if there is a growing class of elite nonwhites, both countries still have deep racial disparities in education, employment, wealth, health and various other metrics (Fassin and Fassin 2006; Omi and Winant 2015). Moreover, there is evidence that even non-white elites face discrimination in the form of career limitations or racialized treatment in the public sphere (Parker and Barreto 2013; Tab 2014). This directly contradicts the first hypothesis:

$\mathrm{H}$ 2: Mainstream media in France and the US exhibit racial bias.

Another set of hypotheses focuses on the different norms for how racial categories operate in the two countries. One possibility is that France's marginalization of race is more effective at promoting egalitarianism (Schnapper 1991) According to this logic the US perpetuates racial divisions and inequality by placing so much emphasis on racial categories. In contrast, the French marginalization of racial categories increases the chances that whites and nonwhites will be treated as equal citizens in the public sphere (Weil 2011).

H3: Mainstream media will exhibit more racial bias in the US than in France.

Another possibility is that the US explicit embrace of racial categorization is more effective at promoting respect for diverse groups (Alba and Foner 2015). Advocates of multicultural recognition argue that when members of the majority group are more aware of minority cultures they will be more accepting of minorities as legitimate and equal citizens (Kymlicka 2003). 
This is important because there is a tendency in all countries for the majority group to have biases against out-group minorities (Tajfel 1982). However, in a country like France, where racial categories are seen as illegitimate for public policy, it is therefore more difficult to develop policies and best practices to combat the racial discrimination that exists in society (Amiraux and Simon 2006). This suggests that whites and non-whites are more likely to be treated equally in the American public sphere where racial categories are openly acknowledged.

H4: Mainstream media will exhibit more racial bias in France than in the US.

\section{Media selection in France and the US}

I analyse data from two national newspapers in each country: Le Figaro and Le Monde in France and the New York Times and USA Today in the US. I select these newspapers because they are evidence of what is significant for the mainstream national community (Atkinson, Lovett and Baumgartner 2014). National newspapers are preferable to specialized sports media that would indicate acceptance in the sports community but not reflect the broader society. I choose print media as opposed to televised media because tennis rankings are updated every week and print media cover tennis throughout the year. This provides a large, fine-grained data source that can analyse change in media coverage and rankings over time. In comparison, there is very little coverage of tennis in the mainstream televised media. There is more televised coverage in the sports networks (e.g. the Tennis Channel or ESPN), but those are indicative of discourse among sports enthusiasts and are less relevant for my focus on the national community.

I include two newspapers in each country to ensure that my results are not driven by the idiosyncrasies or ideological bias of any one paper. Rightleaning newspapers may exhibit more bias against minority players and left-leaning newspapers may focus more on norms of political correctness and either treat non-white players the same as white players or give them preferential coverage (Hall 2000). Therefore, in each country I select one leftleaning paper (Le Monde in France and the New York Times in the US) and one right-leaning paper (Le Figaro and USA Today). ${ }^{4}$

\section{Empirical strategy}

I assess two types of potential racial bias: the amount and the tone of coverage. These are standard measures used by other researchers (Downing and Husband 2005). For the most part I focus on how the amount of coverage does (or does not) vary across white and non-white players, which may be especially appropriate for uncovering covert racial bias in an era when mainstream newspapers are unlikely to use overtly racially charged language. 
A key challenge for research on media bias is determining that observed differences in the amount or the tone of media coverage across races are due to media bias and not actual differences across racial groups. A common strategy is comparing the extent to which a phenomenon occurs among a given subgroup in the population and the extent to which media stories about that phenomenon include the subgroup (Dixon and Williams 2015; Entman and Rojecki 2001). This allows scholars to identify gross misrepresentation of racial minorities in certain kinds of news stories. However, a major drawback is the strong assumption that media coverage of an issue should correspond to the prevalence of that issue among each racial group. This may not be feasible in societies with a wide range of racial minorities and limited media space. In addition, various issues that contribute to newsworthiness and are not related to race (e.g. timeliness of certain events or celebrities from different racial groups) may distort media coverage across races without being related to racial bias.

I propose a new strategy for measuring racial bias in the media. I use the ranking system of professional tennis as a benchmark for how much and what kind of media coverage any player should receive, irrespective of race. This is based on two assumptions. The first is that tennis players with higher rankings should receive more coverage and more positive coverage than tennis players with lower rankings. Mainstream national newspapers focus on the most successful players who are winning the most matches and the most tournaments. This is directly related to rankings because rankings are entirely based on how well players perform in tournaments. Tennis tournaments consist of several rounds. In each round the loser is eliminated and the winner advances to the next round. Players receive points for each tournament depending on what round they are eliminated, with more points going to players who advance further in the tournament. Rankings are based on which players have the most points, so the number one player in the world is the player with the most points, the number two player in the world has the second most points, and so on. ${ }^{5}$ Rankings are updated every Monday based on performance in the tournament from the previous week (most tournaments begin on Monday and end on Sunday). Given the fact that there are tennis tournaments almost every week of the year, this ranking system creates a rolling tally of which players are more successful and therefore more newsworthy in any given week. Being more highly ranked should also lead to more positive coverage, because successful players are - by definition - experiencing more positive outcomes.

My second assumption is that tennis rankings are a useful benchmark for analysing media bias because they are objective. Tennis rankings are based entirely on whether a player wins or loses matches, with no subjective assessments of those matches. Moreover, because tennis is an individual sport, the ranking is a pure indicator of individual success and newsworthiness. Analyses 
of team sports require additional strategies to control for team quality, as the media coverage of any one individual may be correlated with various teamrelated factors (Billings 2004).

The methodological innovation of this approach is that it makes no assumptions about the share of coverage for different races and it allows for variations due to idiosyncratic dynamics that predict newsworthiness, like timeliness of an event or celebrity status. Instead, I make a narrower assumption and identify bias through the relationship between media coverage and objective tennis rankings. If there is a stronger relationship between having a higher ranking and receiving more/better media coverage for white as opposed to non-white players, I consider that reliable evidence of media racial bias.

\section{Data}

I use data from newspaper articles (print and online) published between 1999 and 2013. The time period was chosen to provide contemporary data in each country and stops on 31 December 2013 because that was the end of the most recent calendar year when data were collected. I begin data collection in 1999 because that is when the oldest non-white player (James Blake) who was active in 2013 began his career. ${ }^{6}$ Newspapers do not devote extensive coverage to each of the over 2000 active professional players. Therefore I focus only on the top players from each country, who are the ones most likely to have sufficient data to analyse. The rule for inclusion is that a player must have finished the calendar year ranked among the top 100 players at least once from 1999 to 2013 and must not have begun his professional career prior to 1999. This yields nineteen players from France and seventeen players from the US, who are listed in Table 1 along with the period for which they were professionally active between 1999 and 2013. I limit the analysis to men because while there are several non-white American women who have been consistently ranked in the top 100 over the past decade, there are no non-white French women who meet that requirement, so it is impossible to conduct a cross-national analysis of media bias. Among male tennis players there are three non-whites from the US and two from France who fit the criteria.

I use Lexis-Nexis Academic to search for all articles that mention each player within the respective time frames. I use automated coding to analyse the articles mentioning each player. To measure the extent of coverage I count the number of times a player's name is mentioned each week. ${ }^{7}$ I then analyse how the number of name mentions for each player changes over time according to the player's weekly ranking. ${ }^{8}$ To do this, I construct a panel dataset in which observations are indexed by player and week. There are 783 weeks between 1 January 1999 and 31 December 2013, and 
Table 1. Tennis players and start date of professional singles ranking.

\begin{tabular}{|c|c|c|c|}
\hline \multicolumn{2}{|l|}{ France } & \multicolumn{2}{|c|}{ United States } \\
\hline Thierry Ascione & January 10, 2000 & Brian Baker & January 6, 2003 \\
\hline Julien Benneteau & January 10, 2000 & James Blake & January 4, 1999 \\
\hline Jeremy Chardy & January 10, 2005 & Mardy Fish & April 3, 2000 \\
\hline Kenny de Schepper & January 4, 2010 & Robby Ginepri & January 8, 2001 \\
\hline Nicolas Devilder & January 10, 2000 & Ryan Harrison & November 19, 2007 \\
\hline Richard Gasquet & January 7, 2002 & John Isner & January 1, 2007 \\
\hline Marc Gicquel & April 26, 1999 & Robert Kendrick & January 10, 2000 \\
\hline Michaël Llodra & January 4, 1999 & Bradley Klahn & January 2, 2012 \\
\hline Nicolas Mahut & January 10, 2000 & Jeff Morrison & January 10, 2000 \\
\hline Adrian Mannarino & January 10, 2005 & Sam Querrey & January 2, 2006 \\
\hline Paul-Henri Mathieu & January 4, 1999 & Rajeev Ram & January 12, 2004 \\
\hline Gaël Monfils & January 12, 2004 & Bobby Reynolds & January 6, 2003 \\
\hline Benoît Paire & July 23, 2007 & Andy Roddick & March 6, 2000 \\
\hline Eric Prodon & January 10, 2000 & Tim Smyczek & January 2, 2006 \\
\hline Édouard Roger-Vasselin & January 1, 2007 & Ryan Sweeting & January 1, 2007 \\
\hline Guillaume Rufin & April 21, 2008 & Brian Vahaly & January 8, 2001 \\
\hline Florent Serra & January 10, 2000 & Donald Young & August 2, 2004 \\
\hline Gilles Simon & October 14, 2002 & & \\
\hline Jo-Wilfried Tsonga & January 14, 2004 & & \\
\hline
\end{tabular}

This table lists the players from each country along with the start date for their professional ATP singles ranking, which was used as the first date for the newspaper article search. Players were searched for through December 31, 2013, with the exception of players who retired before that. Jeff Morrison was searched through December 31, 2006, Andy Roddick through December 31, 2012, Brian Vahaly through July 22, 2007, Thierry Ascione through September 26, 2010 and Nicolas Devilder through September 15, 2013. Brian Baker was unranked for several periods of time due to injuries and was not searched for from November 20, 2006-November 11, 2007 and November 24, 2008-July 17, 2011. Non-white players are listed in italics.

36 players, which gives a total of 28,189 possible observations. However, because most players are not actively ranked professionals during each week from 1999 to 2013, I conduct my analysis on a dataset limited to the 19,117 weeks in which players are ranked.

\section{Results}

The mean number of weekly name mentions is 1.11 for a white player and 2.27 for a non-white player. These are fairly small numbers but the standard deviations are large in both countries (more than three times as large as the mean), which reflects the considerable amount of variation in media coverage across players and weeks. In France, a non-white player has a mean number of name mentions (3.70) that is more than four times as large as the mean for a white player (0.79), and this pattern is consistent in both newspapers. In the US, there is roughly the same mean number of mentions for white (1.60) and non-white (1.44) players. $^{9}$

The higher number of average weekly name mentions for non-white players in France is not surprising, as Monfils and Tsonga have been two of the most successful and highly ranked French tennis players during the time period analysed. In comparison, white French players include a 
mixture of very successful and less successful tennis players, who should therefore have fewer average name mentions. By that same logic, it is not surprising that white and non-white players in the US have similar average weekly name mentions. Here, the non-white players range from very successful (Blake) to moderately successful (Young) to less successful (Ram), much like the range of white players. However, to determine whether racial discrimination is present in the media coverage in either country, the key is whether the relationship between name mentions and ranking is the same for whites and non-whites.

Graphs in Figure 1 plot the relationship between ranking and name mentions. For the most part, the general trend in each plot is the same. There is minimal newspaper coverage when players are ranked outside the top 200, but as they get more highly ranked within the top 200 they get more name mentions. This suggests that both countries have similar relationships between ranking and the extent of media coverage for white and nonwhite players.

For a more formal analysis, I estimate linear cross-sectional time-series regressions with random effects. Table 2 presents results from France and the first model suggests that being non-white is associated with more name mentions. Model 2 adds a covariate for weekly ranking, which is

Table 2. Predicting weekly name mentions in France.

\begin{tabular}{lcccc}
\hline & I & II & III & IV \\
\hline Non-White & $2.983^{* * *}$ & $2.778^{* * *}$ & $3.634^{* * *}$ & $3.640^{* * *}$ \\
& $(0.306)$ & $(0.314)$ & $(0.742)$ & $(.0742)$ \\
Rank & & $-0.002^{* * *}$ & $-0.001^{* * *}$ & $-0.001^{* * *}$ \\
& & $(0.000)$ & $(0.000)$ & $(0.000)$ \\
Non-White * Rank & & $-0.009+$ & $-0.009+$ \\
& & & $(0.005)$ & $(0.005)$ \\
Grand Slam & & & $1.281^{* * *}$ \\
& & & & $(0.386)$ \\
French tournament & & & & $1.511^{* * *}$ \\
& & & & $(0.396)$ \\
Davis Cup & & & -0.115 \\
& & $1.069^{* * *}$ & $0.988^{* *}$ & $(0.175)$ \\
Constant & $\left(0.720^{* *}\right.$ & $(0.314)$ & $(0.313)$ & $0.595^{*}$ \\
& 10,901 & 10,901 & 10,901 & $(0.175)$ \\
$N$ & 19 & 19 & 19 & 10,901 \\
Players & 0.037 & 0.051 & 0.057 & 19 \\
Overall $R^{2}$ & 0.058 & 0.038 & 0.041 & 0.085 \\
Rho & & & 0.050 \\
\hline
\end{tabular}

Note: Results from linear cross-sectional time-series regressions with random effects. Dependent variable is the number of weekly name mentions in Le Figaro and Le Monde. Robust standard errors (clustered by player) in parentheses.

$+p<.10$.

${ }^{*} p<.05$.

${ }^{* *} p<.01$.

$* * * p<.001$. 


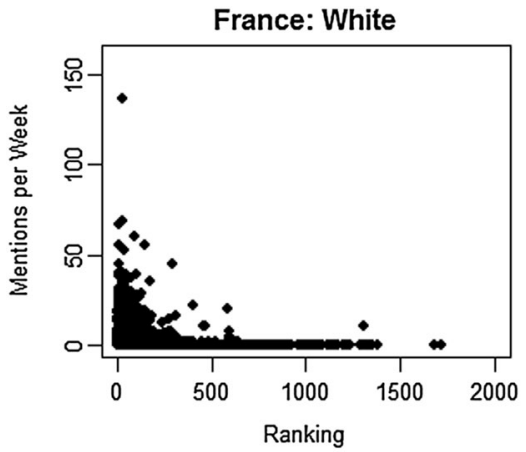

United States: White

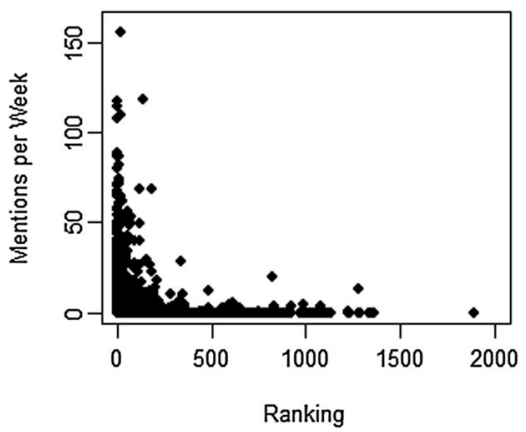

France: Non-White

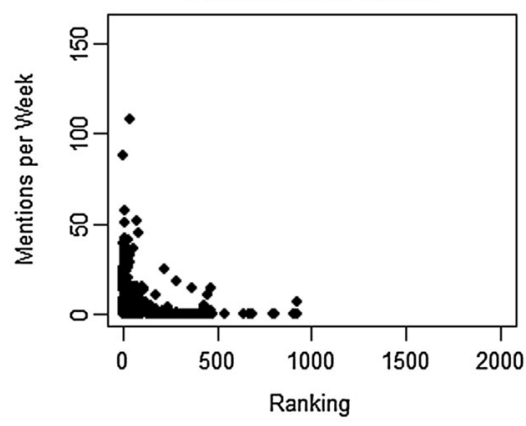

United States: Non-White

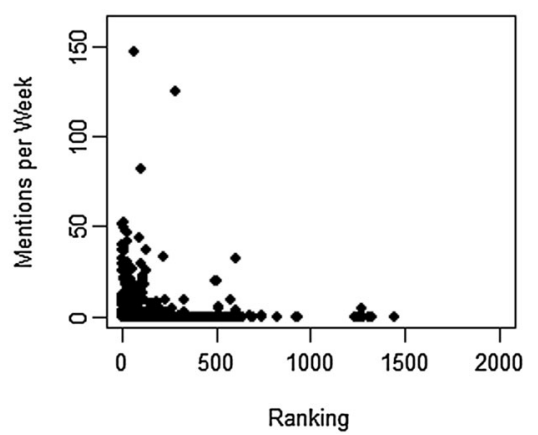

Figure 1. Weekly ranking and number of name mentions.

Weekly rankings and the corresponding number of name mentions. French plots include name mentions in Le Figaro and Le Monde and United States plots include name mentions in the New York Times and USA Today.

statistically significant (at $p<.001$ ) and consistent with expectations as players with lower ranks (i.e. higher ranking numbers) have fewer name mentions. Model 3 adds the key covariate, which is the interaction between race and ranking. This variable is positive and statistically significant (at $p<.10$ ). Model 4 in Table 2 includes three additional covariates to account for the fact that tennis coverage in national newspapers does not occur evenly throughout the year. Major newspapers primarily focus on the four Grand Slam tournaments and local home country tournaments. National newspapers sometimes focus on Davis Cup matches, which is an international tennis event that occurs throughout the year and in which players compete on national teams. If these tournaments are the most important predictor of media coverage and race and ranking are correlated with appearances in these tournaments, the coefficients in model 3 could be biased. However, results in model 4 suggest that the additional covariates do not change the results. 
Table 3. Predicting weekly name mentions in the United States.

\begin{tabular}{lcccc}
\hline & $\mathrm{I}$ & $\mathrm{II}$ & $\mathrm{III}$ & $\mathrm{IV}$ \\
\hline Non-White & -0.139 & -0.208 & -0.294 & -0.298 \\
& $(0.885)$ & $(0.816)$ & $(1.115)$ & $(1.115)$ \\
Rank & & $-0.002^{* *}$ & $-0.002^{* *}$ & $-0.002^{* *}$ \\
& & $(0.001)$ & $(0.001)$ & $(0.001)$ \\
Non-White * Rank & & 0.000 & 0.000 \\
& & & $(0.002)$ & $(0.002)$ \\
Grand Slam & & & $4.388^{* *}$ \\
& & & & $(1.664)$ \\
US tournament & & & & $1.078^{* *}$ \\
& & & & $0.378)$ \\
Davis Cup & & & & 0.038 \\
& $1.357^{*}$ & $1.877^{* *}$ & $1.893^{* *}$ & $(0.110)$ \\
Constant & $(0.595)$ & $(0.702)$ & $(0.727)$ & $0.902^{*}$ \\
& 8216 & 8216 & 8216 & $(0.410)$ \\
$N$ & 17 & 17 & 17 & 8216 \\
Players & 0.000 & 0.020 & 0.020 & 17 \\
Overall $R^{2}$ & 0.082 & 0.059 & 0.063 & 0.065 \\
Rho & & & 0.067 \\
\hline
\end{tabular}

Note: Results from linear cross-sectional time-series regressions with random effects. Dependent variable is the number of weekly name mentions in Le Figaro and Le Monde. Robust standard errors (clustered by player) in parentheses.

$+p<.10$.

${ }^{*} p<.05$.

${ }^{* *} p<.01$.

${ }^{* * *} p<.001$.

Table 3 presents results from the US. Here the non-white variable in model 1 is negatively signed but not statistically significant, even at the 10 percent level. Model 2 adds the covariate for ranking, which is negative and statistically significant (at $p<.01$ ), as expected. The key is the interaction term between race and ranking and it is not statistically significant (even at the 10 percent level) in either model 3 or model 4.

Models in Tables 2 and 3 assume linear relationships between the covariates and the amount of media coverage. However, the diagnostic scatter plots in Figure 1 suggest that the relationship between ranking and media coverage may not be linear. To ensure that my results are not dependent on this specification, I log-transform the ranking variable and re-estimate the models. Full details are in appendix Tables 4 and 5, but the results are consistent with those in Tables 2 and $3 .^{10}$

The stronger relationship between ranking and name mentions for French non-whites could be evidence of racial bias, because it could mean that whites are covered regardless of their ranking while non-whites are only covered when highly ranked. Yet, scatterplots in Figure 1 indicate that neither non-white nor white players receive media coverage when their rankings are low. Moreover, further analysis (presented in the supplementary appendix) suggests that because media coverage is concentrated among the highly ranked, players in both countries who spend more time being 
highly ranked have stronger relationships between ranking and media coverage. This explains the stronger relationships between ranking and media coverage for Monfils and Tsonga, because they have more overall ranking success than the average French white player.

The analysis thus far examines absolute rankings, but changes in ranking might be more important. Dramatic changes in ranking indicate that a player is winning or losing more frequently than usual, which may be considered newsworthy. In addition, it is possible that white and non-white players are covered differently when they exhibit atypical performances. I explore this possibility and present detailed results in the supplementary appendix. The central finding is that when ranking is measured by weekly change there is still no evidence of racial bias in the relationship between ranking and media coverage in either country.

\section{Individual player effects?}

The data in this article include five non-white players. This small number raises the question of whether we can make inferences about the prevalence of racial bias in general, or whether my results are primarily evidence of idiosyncratic relationships between individual non-white players and media coverage. I explore this question in detail in the supplementary appendix and the key finding is that non-white players in France and the United States do not have idiosyncratic relationships that drive their coverage in mainstream national newspapers. The extent that they are more or less likely to be mentioned than other players can be entirely explained by their general level of ranking success.

\section{Tone of coverage}

In this section I use three approaches to analysing potential bias in the tone of media coverage. One possibility is that naming patterns may reflect racialized dynamics. Research suggests that referring to racial minorities by their first name (as opposed to their last name) can be a form of disrespect that reinforces racial hierarchies (Bruce 2004). However, the name mentions for the non-white players in my sample are almost always their full name. The main exception is when the players are mentioned in quotations from other players or coaches who refer to them by the first name. ${ }^{11}$

A second approach to analysing tone uses automated coding. I count the top ten words in association with each player for each week and analyse the extent to which each player is referred to with language that is positive, negative or neutral. ${ }^{12}$ I find that over 99 percent of the words used in association with each player are neutral words that describe the outcome of the tennis matches (e.g. 'set' or 'tournament'). The rare words that have a positive or 
negative value direction, (e.g. 'beat' or 'victory') refer to an objective outcome of the tennis match. The tone does not change dramatically according to player's ranking. This runs counter to my expectations but may reflect the fact that most articles in national newspapers are straightforward factual reports about matches.

My final approach to studying tone is a directed content analysis of the articles in search of language that could reinforce racialized stereotypes and hierarchies. In the US newspapers there is no apparent racialized language when discussing Blake, Ram and Young. Most articles are factual reports about matches but even in-depth profiles are neutral in tone and avoid judgmental or stigmatizing language.

In contrast, French media refer to Monfils and Tsonga exoticizing language that uses racialized tropes of attributing non-white athletic success to genetic endowments, as opposed to the hard work and mental strength that leads to white success (Hughey and Goss 2015). In one of the more egregious examples, Soler (2008) wrote: 'A free spirit, an original bird from the islands whose temperament is fundamentally immersed in a certain lifestyle... even though Monfils grew up in the Paris region ... the ti-punch Gael is sometimes intoxicating.' Despite acknowledging that Monfils was born and raised in Paris, the article insists on his foreignness due to his parents' Caribbean origins. Comparing Monfils to an exotic bird is condescending and the mention of ti-punch (a Caribbean rum-based drink) is a demeaning stereotype that is out-of-place when discussing professional sports. In 2008, Le Figaro (Le Figaro 2008) described Tsonga: 'His strength is both brutal and tranquil. Such serenity ... Tsonga's game is built around having the physique of a Martian.' The descriptors of brutal, tranquil and serene strength evoke a powerful wild animal and the comparison to a Martian has no literal meaning, aside from the connotation that Tsonga's physicality is somehow out of this world. These are dramatic but admittedly rare examples of explicit racialization. More commonly, Monfils and Tsonga are described by French media as athletic, unpredictable, charming showmen who are great 'shotmakers', which are more subtle descriptions but nonetheless evoke racialized tropes of physicality and cognitive inferiority.

These cross-national differences appear to support $\mathrm{H} 4$, because they suggest that French media are more likely than US media to use racialized descriptors for non-white tennis players. However another interpretation is that Monfils and Tsonga are more likely than Blake, Ram and Young to be portrayed as athletic and unpredictable because they are more athletic and unpredictable. To explore this possibility, I review articles in the New York Times and USA Today that mention Monfils and Tsonga and articles in Le Figaro and Le Monde that mention Blake, Ram and Young.

French newspapers are consistent with the American newspapers in not using racialized descriptors for Blake, Ram or Young. ${ }^{13}$ American newspapers 
are consistent with French newspapers in focusing on the physical attributes of Monfils and Tsonga in ways that fit racialized tropes of black athletes (describing them as emotional, flashy, exuberant, high-octane, mercurial and acrobatic showmen). This weakens support for $\mathrm{H} 4$ because it suggests that racialized descriptions of Monfils and Tsonga are not limited to French media. However, the fact that French and American media use different descriptors for different non-white players suggests that the descriptions of Monfils and Tsonga as showmen may be more than racialized stereotypes. Moreover, the main language that is used to describe Monfils and Tsonga is also used - with the same level of frequency - to describe the white French tennis player Gasquet: capricious, enigma, mentally fragile, inconsistent, and flashy shotmaker. This overlap highlights the difficulty of identifying racially biased media tone, because in some respects Monfils, Tsonga and Gasquet may each merit their descriptions as acrobatic showmen.

In short, it would be unwise to attribute athletic descriptions of black tennis players solely to racialized bias. In addition, there is no evidence that nonwhite players are associated with a higher volume of negative or racialized descriptors. Yet, it would be naive to conclude that there is no racialization in the descriptions of Monfils and Tsonga. The combination of being athletic, unpredictable and non-white may explain why the most explicitly racialized Le Figaro articles went further in their descriptions of Monfils and Tsonga than they did for white players like Gasquet, especially given the broader societal stereotypes about cognitive inferiority among non-white athletes (Hughey and Goss 2015). Nonetheless, this is not sufficient to support the notion that there are stronger systematic patterns of bias in France as opposed to the US (H4). It is also worth noting that there is no discernible pattern between ranking and the use of different types of racialized descriptors.

\section{Discussion}

This article finds no evidence of systematic racial bias in the newspaper coverage of male professional tennis players in France and the US and is generally consistent with $\mathrm{H} 1$. There is variation in the relationship between ranking and media coverage across players, but not because of race. The relationship between ranking and media coverage is stronger among players who achieve higher rankings and spend larger percentages of their professional career being highly ranked, irrespective of race. There is some evidence of demeaning racialized tones in French articles about Monfils and Tsonga, but they are a tiny minority of descriptions and not indicative of a systematic trend. Moreover, newspapers describe Monfils, Tsonga and the white French player Gasquet in ways that fit racialized tropes of physicality, which highlights the difficulty of isolating the racialized component of media coverage. 
Despite the lack of evidence of systematic racial bias, one should not interpret the results as proof of racially egalitarian societies in general. Tennis is a useful case study for the progress of racial egalitarianism because of its elite history, but it is possible that racial boundaries might be more salient in the media coverage of other sports. Tennis is a niche sport and the limited coverage in national newspapers may lend itself to brief and objective summaries. More popular sports (e.g. soccer in France or football and basketball in the US) may generate more extensive coverage with more opportunities for media bias. Similarly, non-sporting areas of society may involve different media dynamics, given the fact that racial minority achievement (and in many cases dominance) has become commonplace in sports but not necessarily in other societal arenas.

Another caveat is that my results are primarily evidence of norms among journalists and editors in high-profile newspapers with well-educated readers (Benson 2013). Their behaviour is significant because national newspapers are a key component of mainstream public discourse, but they are not representative of all aspects of public sphere discourse. Research suggests that racial bias in the media is now more commonly expressed in niche outlets like fan-driven blogs, anonymous comments for online news sites, social media postings and internet discussion boards (Love and Hughey 2015). These venues allow people who are not part of the media establishment to become part of media discourse. It is beyond the scope of this article to determine whether racially egalitarian mainstream national newspapers or racially biased niche online comments are more representative of the broad media landscape or of general public opinion. Most likely, both trends are important for understanding the evolution of racial attitudes in North America and Western Europe.

Overall, my findings contribute to ongoing debates about the importance of racial boundaries in different arenas of contemporary society. In particular, my results speak to concerns that overt racial bias in the mainstream national media has been reconstituted as covert bias, which - for the most part - my evidence on male tennis players does not support. Moreover, my findings challenge the juxtaposition of French and American frameworks for racial diversity and suggest that both approaches are compatible with racially egalitarian media. Nonetheless, as my discussion of the nuances of racialized descriptors highlights, many questions remain about when media coverage is racially egalitarian and when it is racially biased.

\section{Notes}

1. One prominent issue is media bias in the coverage of black American tennis players Serena and Venus Williams, although they are beyond the scope of 
this article because there are no highly ranked female French tennis players to serve as a comparison.

2. There are differences in the composition of racial categories across the two countries. Racial diversity in the US has historically been organized around a white-black divide whereas in France the non-white 'other' has been Jewish people, African-origin blacks and North African-origin Arabs at various historical times. For my purposes, these differences are less important than the fact that in both countries there is a hierarchical distinction between whites and nonwhites.

3. Another potentially relevant difference between France and the US is national media systems. For more see the supplementary appendix.

4. See the supplementary appendix for more on other newspaper options.

5. Different types of tennis tournaments offer different numbers of ranking points. The most prestigious 'Grand Slam' events (Australian Open, French Open, Wimbledon and U.S. Open) offer the most (2000 points to the winner, 1200 points to the runner up and a sliding scale that declines in points-awarded for each round). Regardless of how many points are available, players who win more matches have more points and are more highly ranked. For more details see: http://www.atpworldtour.com/Rankings/Rankings-FAQ.aspx

6. As seen below, there are relatively few non-white players in each country, so it was important to get the full dataset for their careers.

7. Each search of newspaper articles was for 'First Name + Last Name + Tennis' to avoid articles about other people with the same name as the tennis players. Comparing these results with those from searches using only 'First Name + Last Name' did not lose any articles about tennis players. Once obtaining the set of articles in which a player is mentioned, the computer makes three calculations. One is the number of mentions of 'First Name', a second is for 'Last Name' and the third is for 'First Name + Last Name'. Each calculation was provided with a $95 \%$ confidence interval, as was the overall calculation of how many times the player's name was mentioned across each of the three measures for each of the weeks.

8. Historical ranking data for each player were obtained from: http://www. atpworldtour.com/Rankings/Rankings-Home.aspx.

9. Appendix tables 1,2 and 3 provide detailed data on weekly name mentions for each player in each newspaper.

10. The results are also consistent when estimated with negative binomial and poisson regression models.

11. Another exception comes from articles about James Blake and Donald Young where there are extensive references to family members and at times the players are referred to as 'James' or 'Donald' to distinguish them from family members. There are also occasional references to Jo-Wilfried Tsonga as 'Jo'. This likely reflects his superstar status as other top (white) players are also referred to by nicknames (e.g. Novak Djokovic is 'Djoker', Roger Federer is 'Fed' and Rafael Nadal is 'Rafa') and nicknames are generally reserved for prominent athletes.

12. Words are considered in association with a player if they occur within ten words of any part of a player's name. This excludes stopwords.

13. Although Blake is known for his powerful forehand shot, he is mainly described in French and American media with words like grace, elegance and intelligence, which celebrates his mental attributes and counters typical racialized tropes for 
non-white athletes. Ram and Young have not been successful enough to receive detailed coverage of their personalities or playing styles.

\section{Acknowledgement}

A previous version was presented at the Council for European Studies Conference of Europeanists. The author would like to thank Mindy Foster for valuable research assistance and Christopher Bail, Frank Baumgartner, Erik Bleich, Irene Bloemraad, John Brigham, Els de Graauw, Paul Statham, Matthew Wright and anonymous reviewers for helpful comments on earlier versions.

\section{Disclosure statement}

No potential conflict of interest was reported by the authors.

\section{Funding information}

Funding for this research was made possible by the University of North Carolina at Chapel Hill.

\section{References}

Alba, Richard, and Nancy Foner. 2015. Strangers No More: Immigration and the Challenges of Integration in North America and Western Europe. Princeton, NJ: Princeton University Press.

Amiraux, Valérie, and Patrick Simon. 2006. "There are No Minorities Here: Cultures of Scholarship and Public Debate on Immigrants and Integration in France." International Journal of Comparative Sociology 47 (3): 191-215.

Atkinson, Mary Layton, John Lovett, and Frank Baumgartner. 2014. "Measuring the Media Agenda." Political Communication 31 (2): 355-380.

Baumgartner, Frank, and Bryan Jones. 2009. Agendas and Instability in American Politics. 3rd ed. Chicago, IL: University of Chicago Press.

Benson, Rodney. 2013. Shaping Immigration News: A French-American Comparison. New York: Cambridge University Press.

Billings, Andrew. 2004. "Depicting the Quarterback in Black and White: A Content Analysis of College and Professional Football Broadcast Commentary." Howard Journal of Communications 15 (4): 201-210.

Bonilla-Silva, Eduardo. 2003. Racism Without Racists: Color-Blind Racism and the Persistence of Racial Inequality in America. 2nd ed. New York: Rowman and Littlefield Publishers.

Bruce, Toni. 2004. "'Marking the Boundaries of the 'Normal' in Televised Sports: The Play-By-Play of Race." Media, Culture \& Society 26 (6): 861-879.

Clarey, Christopher. 2015. "After a 14-Year Boycott, Serena Williams Plans to Play at Indian Wells." New York Times. February 4.

Dixon, Travis, and Charlotte Williams. 2015. "The Changing Misrepresentation of Race and Crime on Network and Cable News." Journal of Communication 65 (1): 24-39.

Djata, Sundiata. 2008. Blacks at the Net: Black Achievement in the History of Tennis, Volume 2. Syracuse, NY: Syracuse University Press. 
Downing, John, and Charles Husband. 2005. Representing 'Race': Racisms, Ethnicity and the Media. London: SAGE Publications.

Emirbayer, Mustafa, and Matthew Desmond. 2015. The Racial Order. Chicago, IL: University of Chicago Press.

Entman, Robert, and Andrew Rojecki. 2001. The Black Image in the White Mind: Media and Race in America. Chicago, IL: University of Chicago Press.

Fassin, Didier, and Eric Fassin. 2006. De la question sociale à la question raciale? Paris: La Découverte.

Gillmeister, Heiner. 1998. Tennis: A Cultural History. London: Bloomsbury Academic.

Givens, Terri, and Case Rhonda Evans. 2014. Legislating Equality: The Politics of Antidiscrimination Policy in Europe. Oxford: Oxford University Press.

Hall, Stuart. 2000. "Racist Ideologies and the Media." In Media Studies: A Reader, edited by Paul Marris and Sue Thornham, 271-282. 2nd ed. New York: New York University Press.

Harris, Cecil, and Kyle-DeBose. Larryette. 2007. Charging the Net: A History of Blacks in Tennis from Althea Gibson and Arthur Ashe to the Williams Sisters. Chicago, IL: Ivan R. Dee.

Hughey, Matthew, and Devon Goss. 2015. "A Level Playing Field? Media Constructions of Athletics, Genetics, and Race." The ANNALS of the American Academy of Political and Social Science 661 (1): 182-211.

Jules, Allain. 2009. "Le No. 1 français de tennis, Jo-Wilfried Tsonga, victime de propos racistes." AgoraVox. February 9.

Kymlicka, Will. 2003. "Multicultural States and Intercultural Citizens." Theory in Research and Education 1 (2): 147-169.

Lamont, Michèle. 2000. The Dignity of Working Men: Morality and the Boundaries of Race, Class, and Immigration. Cambridge, MA: Harvard University Press.

Lee, Taeku. 2002. Mobilizing Public Opinion: Black Insurgency and Racial Attitudes in the Civil Rights Era. Chicago, IL: University of Chicago Press.

Le Figaro. 2008. "Jo-Wilfried Tsonga sur les traces de Noah." Le Figaro, January 25.

Leighley, Jan. 2001. Strength in Numbers? The Political Mobilization of Racial and Ethnic Minorities. Princeton, NJ: Princeton University Press.

Love, Adam, and Matthew Hughey. 2015. "Out of Bounds? Racial Discourse on College Basketball Message Boards." Ethnic and Racial Studies 38 (6): 877-893.

Maxwell, Rahsaan. 2012. Ethnic Minority Migrants in Britain and France: Integration Trade-offs. New York: Cambridge University Press.

Ndiaye, Pap. 2008. La Condition noire. Essai sur une minorité française. Paris: CalmannLévy.

Omi, Michael, and Howard Winant. 2015. Racial Formation in the United States. 3rd ed. New York: Routledge.

Parker, Christopher, and Matt Barreto. 2013. Change They Can't Believe In: The Tea Party and Reactionary Politics in America. Princeton, NJ: Princeton University Press.

Sabbagh, Daniel. 2011. "'Affirmative Action: The US Experience in Comparative Perspective." Daedalus." Journal of the American Academy of Arts and Sciences 140 (2): 109-120.

Schnapper, Dominique. 1991. La France de l'intégration, Sociologie de la nation en 1990. Paris: Gaillimard.

Simon, Patrick. 2008. "The Choice of Ignorance: The Debate on Ethnic and Racial Statistics in France." French Politics, Culture \& Society 26 (1): 7-31.

Sniderman, Paul, and Carmines Edward. 1997. Reaching Beyond Race. Cambridge, MA: Harvard University Press. 
Soler, Cécile. 2008. "Gaël Monfils, joueur en liberté." Le Figaro, June 6.

Tab, Seghier. 2014. Les élus français d'origine maghrébine et la représentation politique. Paris: L'Harmattan.

Tajfel, Henri. 1982. "Social Psychology of Intergroup Relations." Annual Review of Psychology 33: 1-39.

Weil, Patrick. 2002. Qu'est-ce qu'un Français: Histoire de la nationalité française depuis la Révolution. Paris: Grasset.

Weil, Patrick. 2011. Être français: Les quatre piliers de la nationalité. Paris: Éditions de I'Aube.

Wihtol de Wenden, Catherine, and Rémy Leveau. 2001. La beurgeoisie: les trois âges de la vie associative issue de l'immigration. Paris: CNRS Editions.

Wilson, Clint, Félix Gutiérrez, and Lena Chao. 2012. Racism, Sexism and the Media: Multicultural Issues into the New Communications Age. 4th ed. New York: Sage Publications. 